Proc. Estonian Acad. Sci. Eng., 2003, 9, 2, 107-125

\title{
A sea ice dynamics model for the Gulf of Riga
}

\author{
Keguang Wang ${ }^{\mathrm{a}}$, Matti Leppäranta ${ }^{\mathrm{a}}$, and Tarmo Kõuts ${ }^{\mathrm{b}}$ \\ a Department of Physical Sciences, University of Helsinki, P.O. Box 64, FI-00014 Helsinki, Finland; \\ \{keguang.wang, Matti.Lepparanta\}@ helsinki.fi \\ b Marine Systems Institute, Tallinn Technical University, Paldiski mnt. 1, 10137 Tallinn, Estonia; \\ tarmo.kouts@mail.ee
}

Received 17 February 2003

\begin{abstract}
A model for simulating and forecasting the drift of sea ice in the Gulf of Riga, Baltic Sea, is presented. The basin size and ice thickness scale to $100 \mathrm{~km}$ and $30 \mathrm{~cm}$, respectively. The model is based on the conservation and momentum laws of ice with a three-level ice state and viscous-plastic rheology. The steady-state momentum equation is employed; the ice state levels are open water, undeformed ice, and deformed (ridged) ice, together with a dynamic constraint controlling the redistribution process. The model parameters have been estimated by comparing the model outcome with the database of ice charts. Ridging was allowed for ice thicker than $10 \mathrm{~cm}$ and thinner ice rafting in compression.
\end{abstract}

Key words: sea ice dynamics, model, ice thickness distribution, constitutive law, Gulf of Riga.

\section{INTRODUCTION}

The Gulf of Riga is a small brackish water basin in the eastern part of the Baltic Sea, $140 \times 110 \mathrm{~km}$ with mean depth of $26 \mathrm{~m}$ (Fig. 1). It is connected to the Gotland Sea (also known as the Baltic Proper) by Irbe Strait in the west. In the north it is bounded by islands, and the rest of the basin is enclosed by long beaches. In the centre of the basin there is a small oval island of Ruhnu, with a length of the shorter axis about $5 \mathrm{~km}$. Nearby the island the deepest part of the Gulf of Riga is located, where the depth reaches $55 \mathrm{~m}$, otherwise the whole gulf is comparatively flat-bottomed. Ice forms in the Gulf of Riga annually, and the length of the ice season is 3-5 months. In mild winters ice occurs only in the northern part and mainly in the Pärnu Bay, but in normal or severe winters the whole basin freezes over. The thickness of the undeformed drift ice is usually $10-30 \mathrm{~cm}$, and even in a basin of this size the ice ridging takes place resulting in 


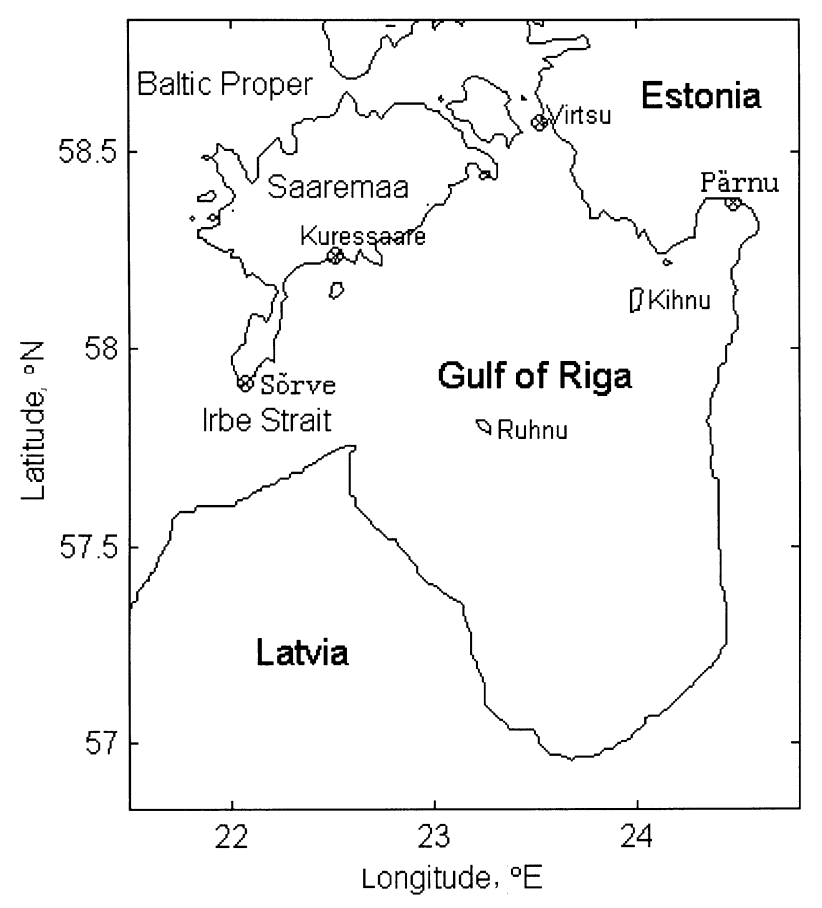

Fig. 1. Morphology of the Gulf of Riga.

deformed ice fields. The presence of ice has a major impact on the physics and ecology of the Gulf of Riga, and the shipping and everyday life on the coast and islands are affected as well.

The motion of drift ice is calculated from the conservation laws of ice and momentum. The ice is driven by winds and currents, and the response of the ice to the forcing depends on the internal stress and on the adjustment of the ice mass distribution. Dynamical drift ice models are characterized by the treatment of the ice medium, i.e., by the ice state description and rheology, which express the relationship between the ice stress and ice state and deformation. The first paper on sea ice modelling was devoted to the two-level linear viscous model $\left[^{1}\right]$. In the seventies, plastic sea ice models were introduced in the Arctic Ice Dynamics Joint Experiment (AIDJEX) program $\left[{ }^{2}\right]$. Paper $\left[{ }^{3}\right]$ describes a viscous-plastic model, which has become the advanced standard for sea ice models. In addition to the successful performance in the polar oceans, the model $\left[{ }^{3}\right]$ describes also ice dynamics in smaller sub-polar seas $\left[{ }^{4,5}\right]$.

In this paper a numerical ice drift model for the Gulf of Riga is presented. It is the first detailed model for this basin, based on a three-level ice state (open water, undeformed ice, and deformed ice) and viscous-plastic rheology. The model calibration has been made using an existing database IDA $\left[{ }^{6}\right]$ with satisfactory outcome. The usual sea ice modelling approach is shown to be valid even for this small basin, so that the optimized model parameters fit into the ranges used in 
larger scale models. This model will be in the future integrated into an operational sea ice forecasting system of the Estonian coastal seas. At present such ice modelling facilities are absent in Estonian meteorological service and operational forecast of ice conditions in Estonian waters is absent yet.

\section{DESCRIPTION OF THE MODEL}

\subsection{Model equations}

Drift ice is a granular, compressible, two-dimensional medium. The "grains" are individual ice floes, which form drift ice particles, and the resulting medium is approximated by a continuum. That is valid if the length scales $d, D$, and $L_{\mathrm{G}}$ of ice floes, drift ice particles, and gradients of drift ice properties, respectively, satisfy the condition $d<<D<<L_{\mathrm{G}}\left[^{7}\right]$. In the Baltic Sea, ice models have produced realistic results down to length scales of $5-10 \mathrm{~km}\left[{ }^{8}\right]$. An ice state $J$ is defined to include the relevant properties of drift ice in each particle. In Baltic Sea models a three-level ice state has been widely used [ $\left.{ }^{9}\right]: J=\left\{A, h_{\mathrm{u}}, h_{\mathrm{d}}\right\}$, where $A$ is the ice compactness, $h_{\mathrm{u}}$ is the thickness of undeformed ice, and $h_{\mathrm{d}}$ is the thickness of the deformed (ridged) ice. They give the total mass per unit area as $m=\rho_{l}\left(h_{\mathrm{u}}+h_{\mathrm{d}}\right) A$, where $\rho_{l}=0.9 \mathrm{Mg} / \mathrm{m}^{3}$ is ice density.

The basic equations for sea ice dynamics are the conservation laws of momentum and ice $\left.{ }^{7}\right]$. The former is

$$
m \frac{\mathrm{d} \mathbf{V}}{\mathrm{d} t}=-m f \mathbf{k} \times \mathbf{V}+\boldsymbol{\tau}_{\mathrm{a}}+\boldsymbol{\tau}_{\mathrm{w}}-m g \nabla \xi+\nabla \cdot \boldsymbol{\sigma},
$$

where $\mathrm{d} / \mathrm{d} t$ is the substantial time derivative, $\mathbf{V}$ is the ice velocity, $f$ is the Coriolis parameter, $\mathbf{k}$ is the upward unit vector normal to the surface, $\boldsymbol{\tau}_{\mathrm{a}}$ and $\boldsymbol{\tau}_{\mathrm{w}}$ are the air and water stresses, $g$ is the gravity acceleration, $\xi$ is the sea surface elevation, and $\boldsymbol{\sigma}$ is the internal ice stress. The air and water stresses are determined by the formulae

$$
\begin{gathered}
\boldsymbol{\tau}_{\mathrm{a}}=\rho_{\mathrm{a}} C_{\mathrm{a}}\left|\mathbf{V}_{\mathrm{a}}\right|\left(\mathbf{V}_{\mathrm{a}} \cos \varphi+\mathbf{k} \times \mathbf{V}_{\mathrm{a}} \sin \varphi\right), \\
\boldsymbol{\tau}_{\mathrm{w}}=\rho_{\mathrm{w}} C_{\mathrm{w}}\left|\mathbf{V}_{\mathrm{w}}-\mathbf{V}\right|\left[\left(\mathbf{V}_{\mathrm{w}}-\mathbf{V}\right) \cos \theta+\mathbf{k} \times\left(\mathbf{V}_{\mathrm{w}}-\mathbf{V}\right) \sin \theta\right],
\end{gathered}
$$

where $\rho_{\mathrm{a}}, \rho_{\mathrm{w}}$ are air and water densities, $C_{\mathrm{a}}, C_{\mathrm{w}}$ are air and water drag coefficients, $\mathbf{V}_{\mathrm{a}}, \mathbf{V}_{\mathrm{w}}$ are wind and current velocities, and $\varphi, \theta$ are boundary layer turning angles for air and water. The inertial time scale of thin ice is much less than one hour, and a quasi steady-state approach is used. Also in the Gulf of Riga conditions the pressure gradient due to the sea surface slope and momentum advection are small compared with other terms and are ignored here.

A rheological equation is needed to describe the mechanical behaviour of drift ice. This equation describes how the stress within a drift ice field depends on its state and deformation. In general $\boldsymbol{\sigma}=\boldsymbol{\sigma}(J, \boldsymbol{\varepsilon})$, where $\boldsymbol{\varepsilon}$ is the strain rate and $\varepsilon_{i j}=\left(\partial u_{i} / \partial x_{j}+\partial u_{j} / \partial x_{i}\right) / 2$. Stress and strain rate are 2 nd order tensors, which 
have four components in a two-dimensional space. The general form tells that drift ice is a fluid but, as is described below, it is a highly non-linear fluid with a plastic limit behaviour. In the plastic regime the stress has achieved the yield limit and then the strain rate depends on the yield criterion. The main features of the mechanical behaviour of the drift ice are that stresses are significant only under compressive deformation and when the ice compactness is high, more than about 0.8 .

In the present work the common approach, using a viscous-plastic ice rheology model $\left[^{3}\right]$, is used. This gives a linear viscous law for small strain rates and a plastic law with an elliptic yield curve for large strain rates, written as

$$
\sigma_{i j}=2 \eta \varepsilon_{i j}+\left[(\zeta-\eta) \varepsilon_{\mathrm{I}}-P / 2\right] \delta_{i j},
$$

where $\zeta$ and $\eta$ are non-linear bulk and shear viscosities, $\delta_{i j}$ is Kronecker tensor, $\varepsilon_{\mathrm{I}}=\varepsilon_{11}+\varepsilon_{22}$ is the 1 st strain rate invariant equal to the divergence of the velocity, and $P$ is ice strength

$$
P=P^{*} \bar{h} \exp [-C(1-A)] .
$$

Here $\bar{h}$ is mean ice thickness, $P^{*}$ is compressive strength of ice of unit thickness, and $C$ is the strength reduction constant for lead opening. The viscosity coefficients are functions of the strain rate invariants and ice strength:

$$
\zeta=P / 2 \Delta, \quad \eta=\zeta / e^{2},
$$

where $\Delta=\max \left\{\Delta_{0},\left(\varepsilon_{\mathrm{I}}^{2}+e^{-2} \varepsilon_{\mathrm{II}}^{2}\right)^{1 / 2}\right\}, \Delta_{0}$ is maximum linear viscous creep rate, $e$ is the ratio of compressive strength to shear strength or the aspect ratio of the yield ellipse, and $\varepsilon_{\mathrm{II}}$ is the 2 nd strain rate invariant equal to the maximum rate of shear (obtained as the difference of the principal values of the strain rate tensor). This rheology thus includes four parameters: $P^{*}, C, e$, and $\Delta_{0}$.

In this work the short-term sea ice processes are examined and the thermodynamic effects are neglected. The conservation of ice then gives

$$
\frac{\partial}{\partial t}\left\{A, h_{\mathrm{u}}, h_{\mathrm{d}}\right\}=-\mathbf{V} \cdot \nabla\left\{A, h_{\mathrm{u}}, h_{\mathrm{d}}\right\}+\left\{\psi_{\mathrm{A}}, \psi_{\mathrm{u}}, \psi_{\mathrm{d}}\right\},
$$

where $\psi_{\mathrm{A}}, \psi_{\mathrm{u}}, \psi_{\mathrm{d}}$ are the ice redistribution functions due to mechanical deformation. Three cases arise: opening and closing of leads, rafting of thin ice $\left(h_{\mathrm{u}}<h_{\mathrm{cr}}\right)$ or ridging $\left(h_{\mathrm{u}}>h_{\mathrm{cr}}\right) ; h_{\mathrm{cr}}$ is the maximum rafting thickness.

Opening and closing of leads: $A<1$ or $\nabla \cdot \mathbf{V} \geq 0$, only concentration changes, hence $\psi_{\mathrm{u}}=\psi_{\mathrm{d}}=0$ and $\psi_{\mathrm{A}}=-A \nabla \cdot \mathbf{V}$.

Rafting: $A=1, \nabla \cdot \mathbf{V}<0$ and $h_{\mathrm{u}} \leq h_{\mathrm{cr}}$, level ice thickness increases, therefore $\psi_{\mathrm{A}}=\psi_{\mathrm{d}}=0$ and $\psi_{\mathrm{u}}=-\bar{h} \nabla \cdot \mathbf{V}$ (note that rafted ice is treated as undeformed ice since it is more like layered undeformed ice in appearance and properties).

Ridging: $A=1, \nabla \cdot \mathbf{V}<0$ and $h_{\mathrm{u}}>h_{\mathrm{cr}}$, deformation changes only the ridge component; thus $\psi_{\mathrm{A}}=\psi_{\mathrm{u}}=0$ and $\psi_{\mathrm{d}}=-\bar{h} \nabla \cdot \mathbf{V}$. 


\subsection{Numerical solution}

The momentum equation and the ice conservation law are solved numerically using a staggered, spatial grid configuration (Arakawa B grid, Fig. 2). For the momentum equation, the main steps are outlined in $\left[^{5}\right]$. The steady state equation is first iterated to the solution. With a given ice velocity, a new corrected value is obtained with the overrelaxation method from the linearized momentum equation. The corrected velocity is used as an input to a new overrelaxation, and the cycle is repeated until the desired accuracy, i.e., until the correction given by one cycle is small enough. Then with the obtained ice velocity, for the prognostic equation of ice state, a modified Lax-Wendroff scheme is employed with the two-step procedure. The dynamic constraint terms are included in the second step. To increase the computational stability, second- and fourth-order horizontal diffusion terms are also added in the second step.

\section{ICE CONDITIONS}

\subsection{General}

The Gulf of Riga is located in the eastern coast of the Baltic Sea, bordering Estonia and Latvia (Fig. 1). Its form is oval, the size is $140 \times 110 \mathrm{~km}$, the surface area is $16,400 \mathrm{~km}^{2}$, and the mean depth is $26 \mathrm{~m}$ on a comparatively flat bottom topography. In normal and severe winters the basin is ice-covered, whereas in mild winters ice is often confined only in shallow coastal areas and in NE of the gulf. The thickness of undeformed drift ice ranges around $10-30 \mathrm{~cm}$, and depending on the morphology of the bay and wind conditions heavier or lighter ice ridging takes place. However, quantitative data of the amount of ridging in the Gulf of Riga are not available, even general long-term statistics of ridging

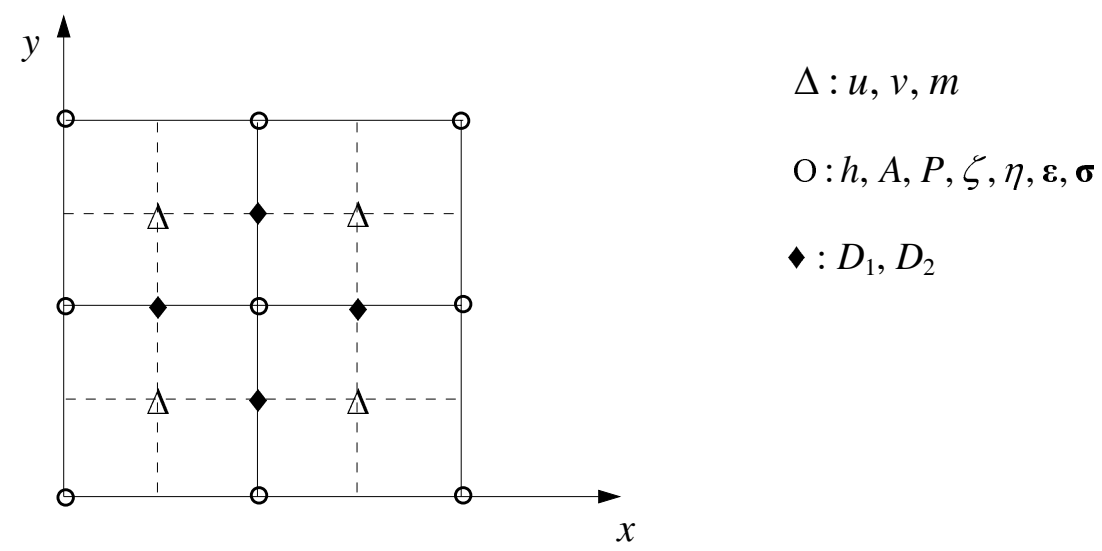

Fig. 2. Configuration of variables used in the model; $D_{1}, D_{2}$ - second- and fourth-order diffusion coefficients. 
events is poorly known. Statistics for the freezing, thickness, and breakup of landfast ice are given in $\left[{ }^{10}\right]$.

Since 1990 mild winters have frequently occurred, making it difficult to collect new field data for ice research. Also the intensity and nomenclature of routine ice observations decreased remarkably during the last decade thus adding on the difficulties to obtain good understanding of ice dynamic processes. There are descriptions of severe ice ridging events near Ruhnu and Kihnu islands. However, these data are distributed over a number of sources and have never been analysed together; they could still be useful in further model development. In the last two years, useful ice information has been obtained from medium and high resolution satellite imagery, especially for the opening and closing of leads. Satellite data are available also backward in time from monitoring systems such as MODIS or LANDSAT.

The well-documented (in the Baltic Sea) winters 1983/84 and 1986/87 from the IDA database $\left[{ }^{6}\right]$ constitute the main data set used in the present work. These data of two winters represent a normal (1983/84) and a severe (1986/87) winter. However, because of the low resolution of these data, detailed investigations in the Gulf of Riga cannot be performed. Two particular cases, in which significant movement of the ice pack occurred, were taken from the IDA database for model calibration. Surface wind data for these cases have been obtained from Estonian meteorological stations, and for the actual computation the wind data of Sorve station with 3-hour time interval was used. The wind data of other stations were analysed together and seemed to include local effects, which restricted their usage for model calculations. Stations of the eastern coast in Kihnu, Virtsu, and Pärnu give lowered wind speeds and the wind direction is affected by the coastline morphology. Comparison of surface and geostrophic winds showed that data of Sorve station reflect well wind conditions over the open sea, where the ice sheet gets most of its actual "wind stress load". There is an even more ideal wind station, Ruhnu, in the centre of the Gulf of Riga, but local conditions (mainly too high trees near the station) influence the wind regime and make it non-adequate to represent the open sea conditions.

As an example, the ice situation on 2 February in the severe winter 1987 is shown in Fig. 3. There is fast ice in the northern part of the basin, sticking on the Estonian coast. The fast ice boundary generally coincides with the $10 \mathrm{~m}$ isobath in normal and severe winters and with the Suur Strait in the north. This strait plays an important role in the water exchange between the Gulf of Riga and the Gotland Sea $\left.{ }^{11,12}\right]$. At the fast ice boundary, the leads open when drift ice moves further out or leads close and ridging takes place during onshore motion. The drift ice field of variable compactness normally covers most of the gulf, and a lead commonly appears in the southern part, caused by southerly winds dominating during winter months. Nevertheless, the ice chart is deficient for a sufficiently fine scale information of the ice properties - concentration and thickness as the main parameters. From Fig. 3a the ice thickness can be seen only at some locations in the Gulf and in the central part of the basin. This information 


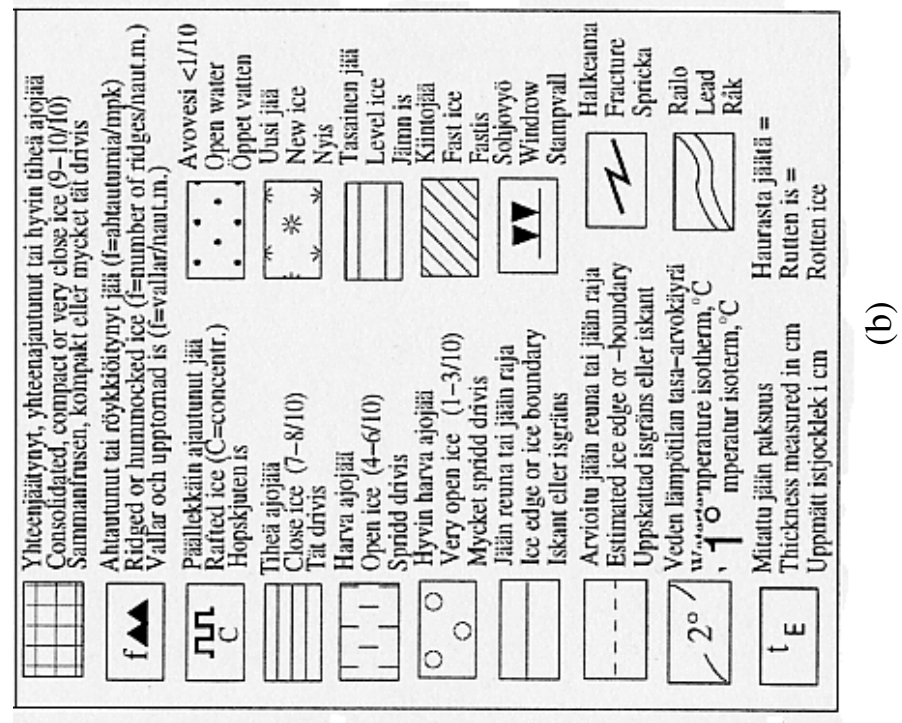

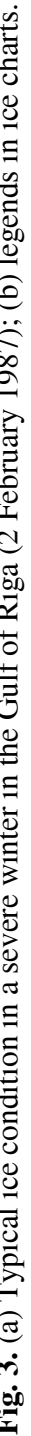

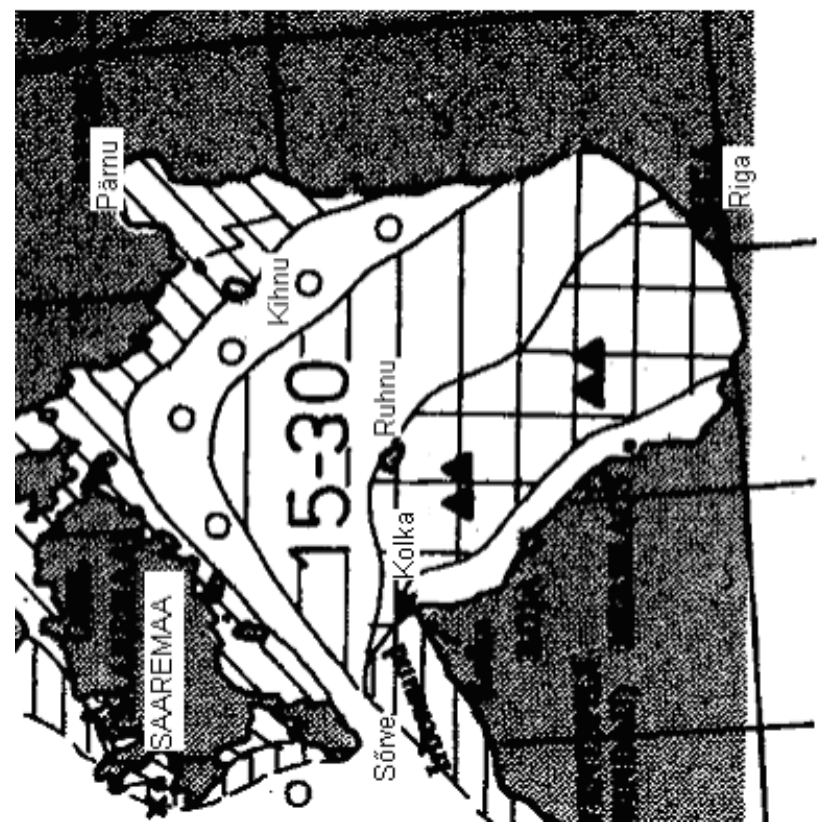


definitely is not enough for practical purposes, for icebreaking service or navigation. Practical observations have shown that ice thickness, compactness, and ridging vary in a wide range over the Gulf of Riga.

\subsection{Dynamical characteristics}

The principal scales of drift ice dynamics in the Gulf of Riga are as follows: basin size $L=100 \mathrm{~km}$, ice thickness $H=20 \mathrm{~cm}$, and wind speed $U_{\mathrm{a}}=10 \mathrm{~m} \mathrm{~s}^{-1}$. The free drift ice speed becomes $25 \mathrm{~cm} \mathrm{~s}^{-1}$ from the wind and drag parameters, and the wind and water stresses in free drift are $0.2 \mathrm{~Pa}$. Then, because of the small thickness of the ice, inertial time scale is $5 \mathrm{~min}$ and the Coriolis term, momentum advection, and surface pressure gradient are more than one order of magnitude below the surface values. The internal friction term scales to $P^{*} H / L \sim 0.2 \mathrm{~Pa}$. Consequently, the momentum equation is dominated by the wind stress, water stress, and the internal friction. Note that, as a characteristic of the plastic rheology, the internal friction is independent of the ice velocity while wind and water stresses are quadratic in air and ice velocities, respectively, and that internal friction is proportional to the ice thickness while wind and water stresses are independent of that. As a result, the ice moves easily when it is thin or strongly forced and the relative motion increases with forcing.

\subsection{Selected cases}

\subsubsection{Case 1 (27 February-19 March 1984)}

The ice conditions were quite similar to the long-term average during (normal) winter of 1983/84 in the Baltic Sea. The ice conditions in the Gulf of Riga during this period are shown in Fig. 4. In the beginning the whole basin was ice-covered; in the south with comparably thin new ice, which disappeared three days later. The thickness of the ice in the central gulf was $10-20 \mathrm{~cm}$ with more heavy ice conditions in the north of the basin. This is an ideal case for an ice dynamics study. Because of the limited area of the ice pack, it possessed a high capability of moving. On 27 February, the pack was in NW of the gulf, while by 5 March it had gone to the NE side. Through 8-19 March, the ice slowly returned to the NW side of the basin. The charts show that the ice field was compact or closely packed (compactness more than 0.7 ) most of the time, a narrow open drift ice zone was found in the southern and SW part of the gulf in mid-March. A remarkable characteristic in all the ice charts is that the drift ice cover did not diffuse but was preserved always as one whole pack. And no significant deformation occurred when the ice cover moved against the coast and the fast ice zone. In addition to the movement of the drift ice, the change of the landfast ice zone was also noticeable. After 12 March this zone was divided into two parts, one remaining landfast and another joining the drift ice. 

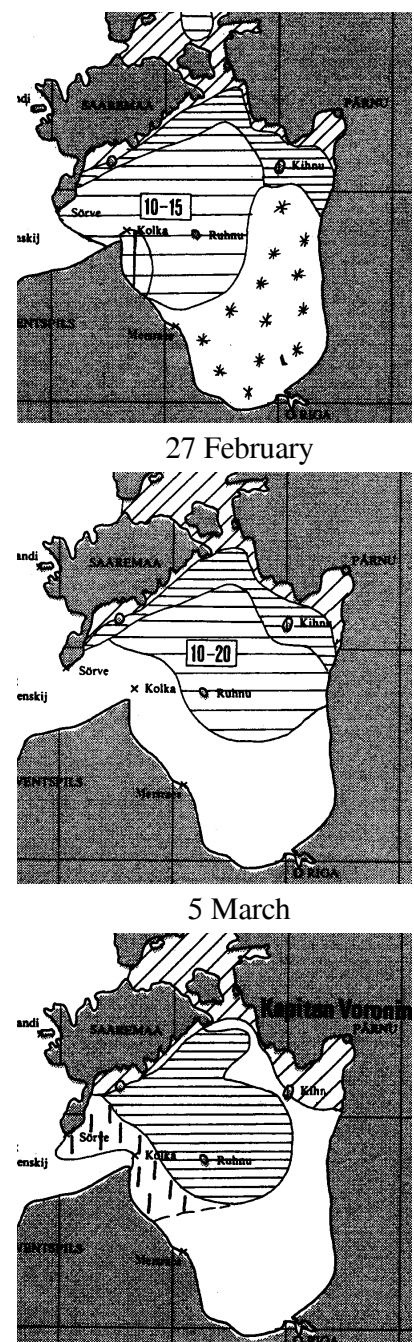

12 March

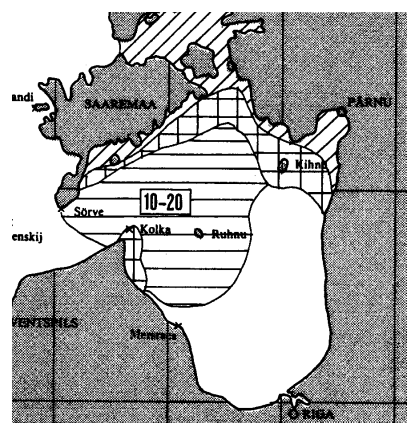

1 March

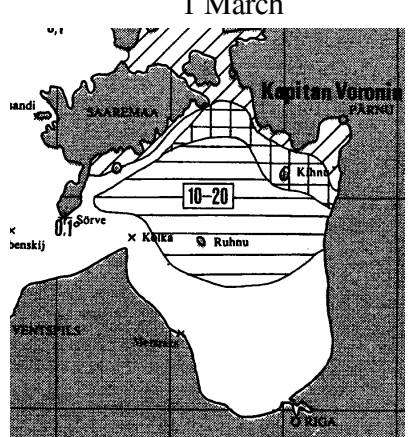

8 March

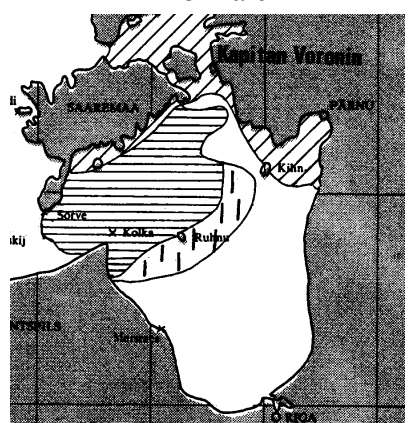

15 March

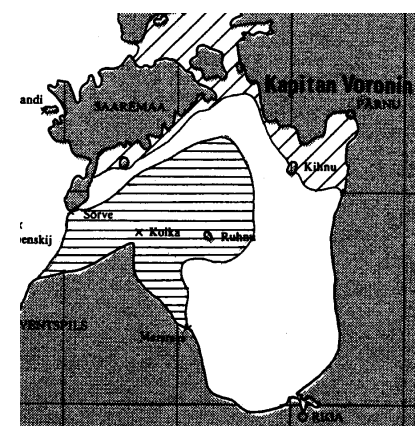

19 March

Fig. 4. Observed ice conditions in the Gulf of Riga from 27 February to 19 March 1984, representing a normal winter (notations are shown in Fig. 3b). 


\subsubsection{Case 2 (19-29 January 1987)}

The ice conditions were most severe in the Baltic Sea during the winter 1986/87. As early as on 12 January 1987, the Gulf of Riga was all covered by ice. On 19 January the thickness of ice reached mostly $5-15 \mathrm{~cm}$, with some rafted ice in the western part of the gulf (Fig. 5). In 19-22 January the ice moved NE with rafting taking place, and the ice thickness had increased to $15-30 \mathrm{~cm}$ by the 22nd of January. Then the movement turned into the opposite direction and rafting appeared. Then heavy ridging took place in a wide sea area in the SW part of the basin during 26-29 January. Despite the limited area of lead increasing in the north, the ridging area occupied more than one third of the total gulf area. This is a typical case showing the mode of sea ice deformation changing from rafting to ridging, in which the maximum ice thickness in rafting, $h_{\mathrm{cr}}$, was around $15-30 \mathrm{~cm}$. Considering studies in other parts of the Baltic Sea, $h_{\mathrm{cr}}$ is likely in the lower range of this interval; according to a theoretical rafting model $\left[{ }^{13}\right]$, $h_{\mathrm{cr}} \approx 10 \mathrm{~cm}$ for Baltic ice.

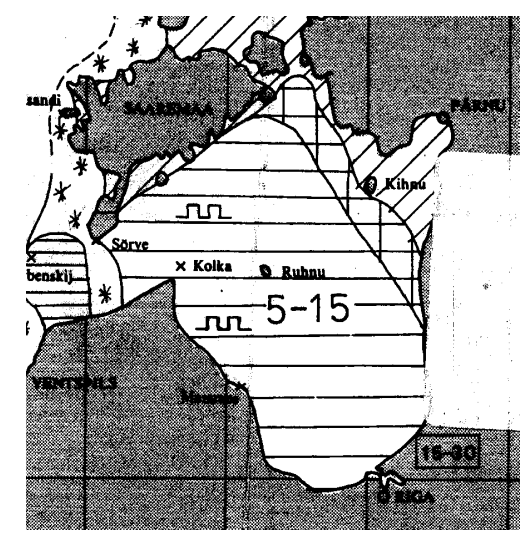

19 January

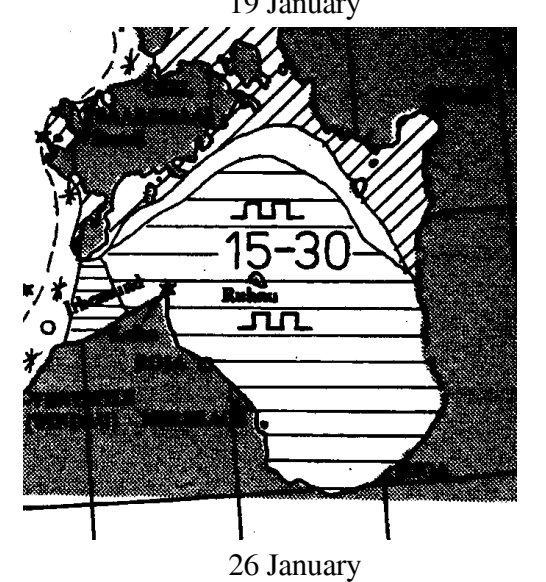

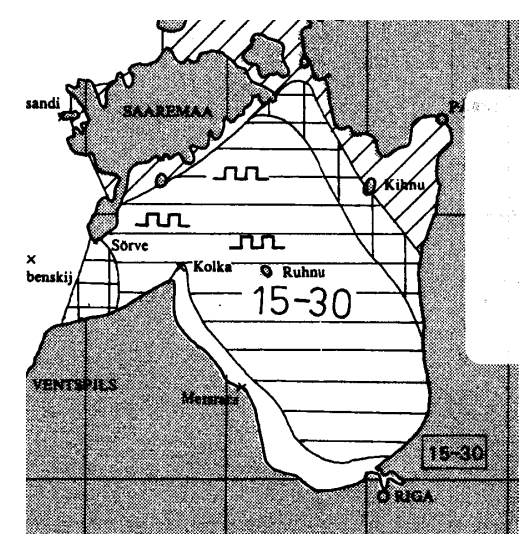

22 January

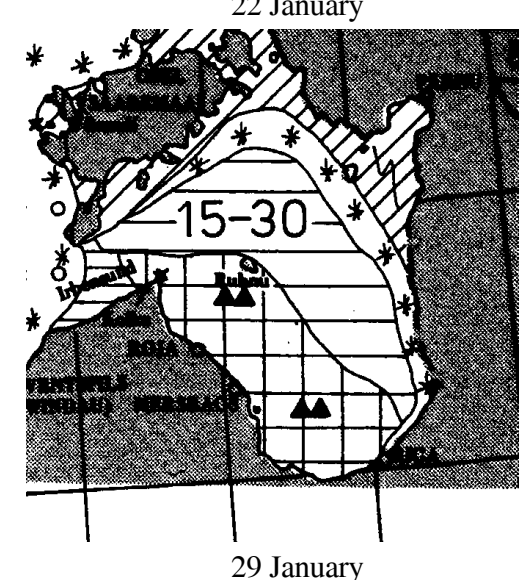

Fig. 5. Observed ice conditions from 19 to 29 January 1987, representing a severe winter (notations are shown in Fig. 3b). 


\section{MODEL SIMULATIONS}

The initial ice thickness and ice concentration were obtained from the ice charts shown in Figs. 4 and 5. Short-range (3 or 4 days) simulations were performed using each ice chart as an initial field. Typical values of the drift ice thickness were chosen as follows: $13 \mathrm{~cm}$ on 27 February and $15 \mathrm{~cm}$ on other days in 1984, and $9 \mathrm{~cm}$ on 19 January and $23 \mathrm{~cm}$ on other days in 1987. Big variation of the ice thickness in 1987 was probably due to the thermodynamic growth of the ice thickness. The ice concentration was taken 0.8 for close ice and 0.99 for level ice, very close ice, rafted ice, and ridged ice. The landfast ice was all set to $25 \mathrm{~cm}$ with ice concentration of 0.99 . For the wind forcing the surface wind in Sõrve (Fig. 1) was used, with time interval of $6 \mathrm{~h}$. The current velocity beneath the layer of frictional influence of the ice was set to zero. We have made comparisons between surface wind forcing and geostrophic wind forcing obtained from Swedish Meteorological and Hydrological Institute database and found that the surface wind forcing provides more realistic ice dynamics. The grid size is $1 \mathrm{nmi}$, and the time step is $30 \mathrm{~min}$. The parameters used in the standard simulation are shown in Table 1. The free drift parameters are from a Baltic Sea study $\left[{ }^{14}\right]$ and the ice rheology parameters are from the present tuning for $P^{*}$ while the other parameters have standard values $\left[{ }^{3,4}\right]$.

\subsection{Simulation results of Case 1}

The wind was weak or moderate all the period, from 26 February to 19 March 1984 (Fig. 6). The maximum wind speed was only $12 \mathrm{~m} \mathrm{~s}^{-1}$. With a qualitative tracking of the ice drift based on the wind reveals inconsistencies in some of the ice charts. There seems to be a time lag between ice charts and wind fields, i.e., some ice fields would have been more reasonable if they had been timed half a day earlier than they were referred to. The reason for that may be that ice data are collected continuously by the ice information services and some of the information is already old at the time when a chart is printed.

Table 1. Numerical parameters used in the standard simulation

\begin{tabular}{|c|c|c|c|}
\hline Air: & $\begin{array}{l}\rho_{\mathrm{a}}=1.3 \mathrm{~kg} \mathrm{~m}^{-3} \\
C_{\mathrm{a}}=0.0018 \\
\varphi=0^{\circ}\end{array}$ & Water: & $\begin{array}{l}\rho_{\mathrm{w}}=10^{3} \mathrm{~kg} \mathrm{~m}^{-3} \\
C_{\mathrm{w}}=0.0035 \\
\theta=15^{\circ}\end{array}$ \\
\hline Ice: & $\begin{array}{l}\rho_{\mathrm{i}}=910 \mathrm{~kg} \mathrm{~m}^{-3} \\
P^{*}=3.0 \times 10^{4} \mathrm{~N} \mathrm{~m}^{-2} \\
C=20 \\
e=2 \\
\Delta_{0}=1.0 \times 10^{-9} \mathrm{~s}^{-1} \\
h_{\mathrm{cr}}=0.10 \mathrm{~m}\end{array}$ & $\begin{array}{l}\text { Numerical } \\
\text { solution: }\end{array}$ & $\begin{array}{l}\Delta x=1852 \mathrm{~m} \\
\Delta y=1852 \mathrm{~m} \\
\Delta t=30 \mathrm{~min} \\
D_{1}=7.4 \mathrm{~m}^{2} \mathrm{~s}^{-1} \\
D_{2}=-1.9 \times 10^{3} \mathrm{~m}^{2} \mathrm{~s}^{-1}\end{array}$ \\
\hline
\end{tabular}



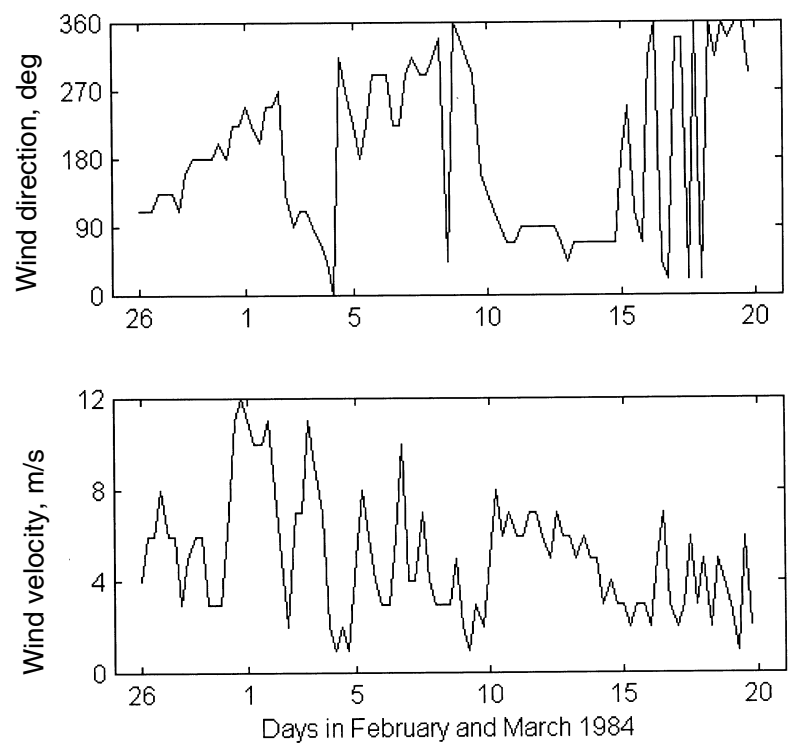

Fig. 6. Wind direction and velocities in Sõrve in February and March 1984, the wind direction is counted clockwise from the north.

Figure 7 illustrates the simulated ice thickness fields with two different ice strength constants $P^{*}$. Main difference is that the higher strength gives only little motion, while the lower strength creates a ridging zone in NE of the gulf. However, such ridging is not supported by observations, and thus the higher strength represents better this ice field; however, a little higher strength is not ruled out. Note that the Ruhnu island causes mechanical accumulation and thinning on its drift and lee sides, as happens with the pressure field for a fluid flow past a circular obstacle.
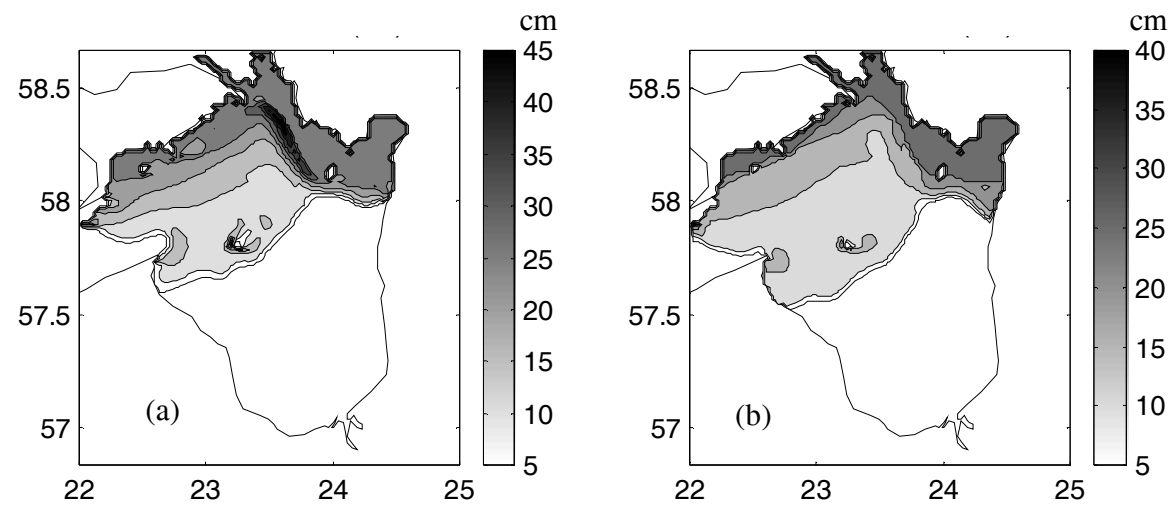

Fig. 7. Simulated ice thickness fields from 27 February to 1 March 1984 with two compressive strengths of drift ice: (a) $P^{*}=1.0 \times 10^{4} \mathrm{~N} \mathrm{~m}^{-2}$; (b) $P^{*}=3.0 \times 10^{4} \mathrm{~N} \mathrm{~m}^{-2}$. 
A seven-day simulation is performed from the initial ice state of 1 March 1984 (Fig. 8). The result compares well with the real ice chart for 8 March, while for 5 March the model gives to the ice too much shifting to the west (Fig. 4). However, the simulation result for 4 March exhibits more similarity to the ice chart of 5 March. Thus it is quite possible that this chart represents rather the ice conditions on 4 March.

There was a noticeable melting of ice on 8-19 March which makes it difficult for the pure dynamic model to simulate the evolution of the ice conditions during this period. The initial ice concentration on 8 March was set to 0.8 . The modelled ice concentration and thickness on 12 March shows a triangular open water area (Fig. 9), which appeared similarly in the ice chart. Since the ice concentration and consequently the ice strength is low, it is very difficult to find a good estimate for the strength constant $P^{*}$.

The resulting ice thickness fields from the model simulation for time periods from 12 to 15 March and from 15 to 19 March are shown in Fig. 10. The completely open ice patches are ignored in the initial fields, because they melted during the period of investigation. Comparing the model outcome with the ice charts shows that the dynamic model is basically capable to simulate the situation when melting region is excluded.
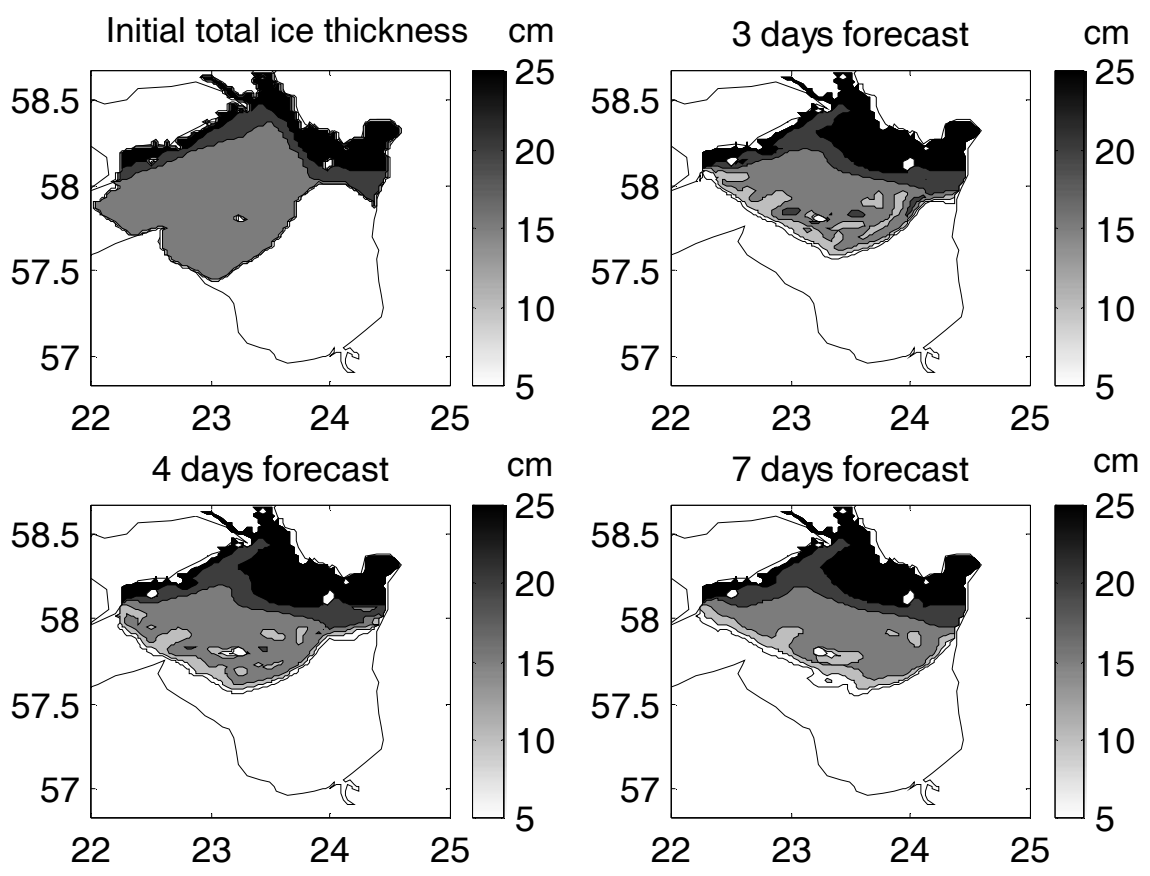

Fig. 8. Simulation of the ice thickness field from 1-8 March 1984. 

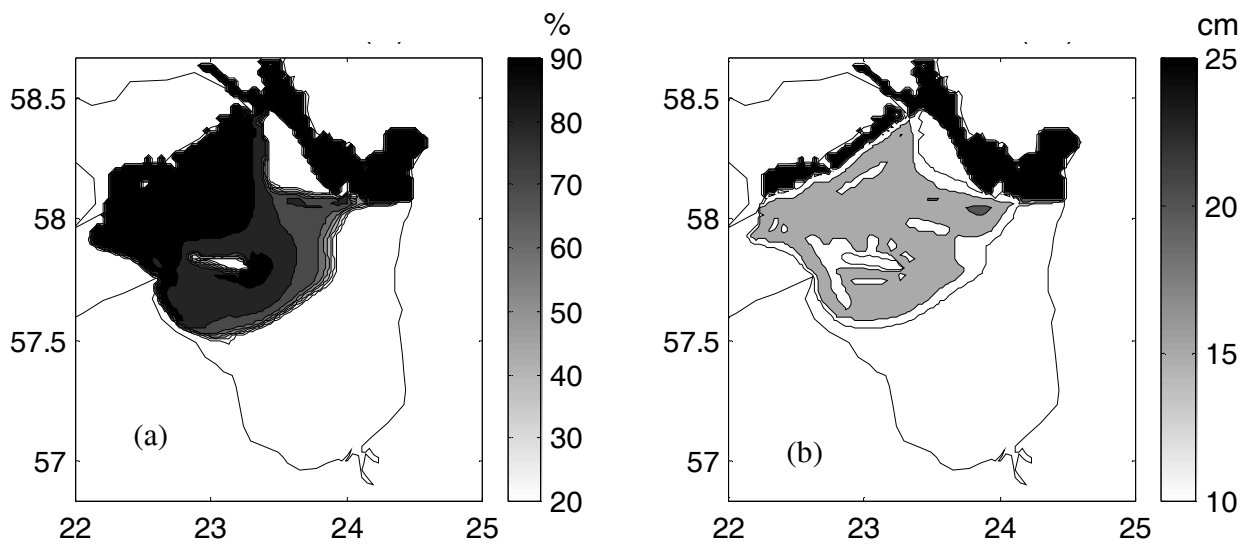

Fig. 9. Standard model simulation from 8 to 12 March 1984: (a) ice concentration; (b) ice thickness.
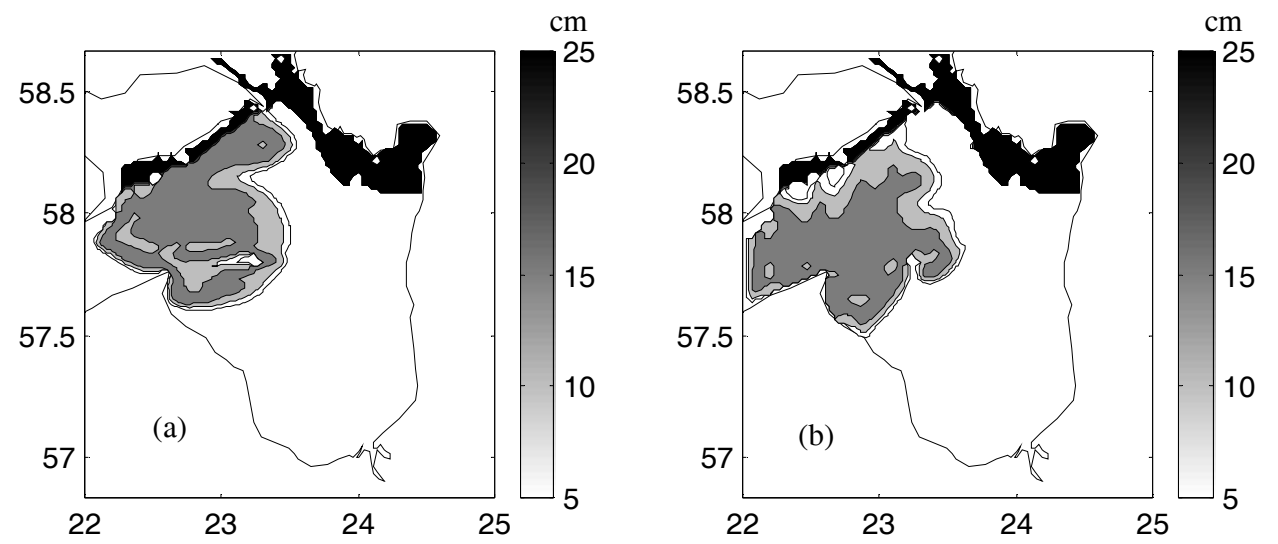

Fig. 10. Standard model simulation of ice thickness fields: (a) 12 to 15 March 1984; (b) 15 to 19 March 1984.

\subsection{Simulation results of Case 2}

In the period of study (19-29 January 1987) moderate westerly winds prevailed before 25 January, wind speed being generally lower than $10 \mathrm{~m} \mathrm{~s}^{-1}$ (Fig. 11). Then a strong NW wind rose over the basin, and the wind stayed strong until 28 January.

The modelled ice concentration and thickness on 22 and 26 January are shown in Figs. 12 and 13. The model results agree quite well with the ice chart; however, numerical experiments indicate that the simulation results are quite sensitive to the initial ice thickness. When the initial ice concentration is set to one, ice cover remains unchanged if ice thickness is about $15 \mathrm{~cm}$. Nevertheless, when ice concentration is set to less than 0.9 or equivalently the strength constant $P^{*}$ is reduced, the model is very close to the ice chart. This implies that ice strength is very low when the ice thickness is less than $10 \mathrm{~cm}$. A similar result 

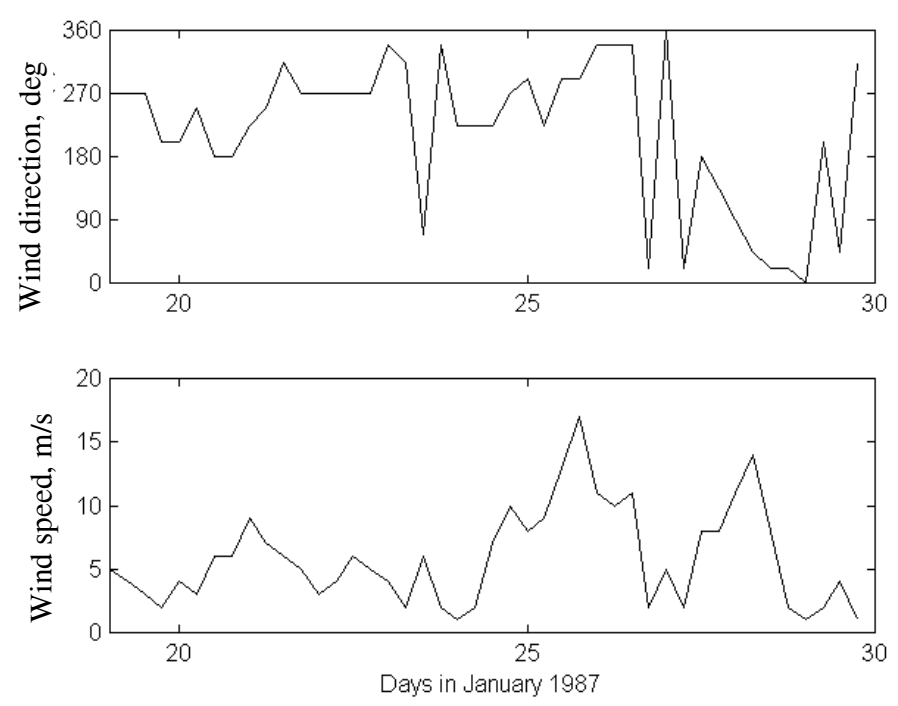

Fig. 11. Wind characteristics in January 1987 in Sõrve (the wind direction is counted clockwise from the north).

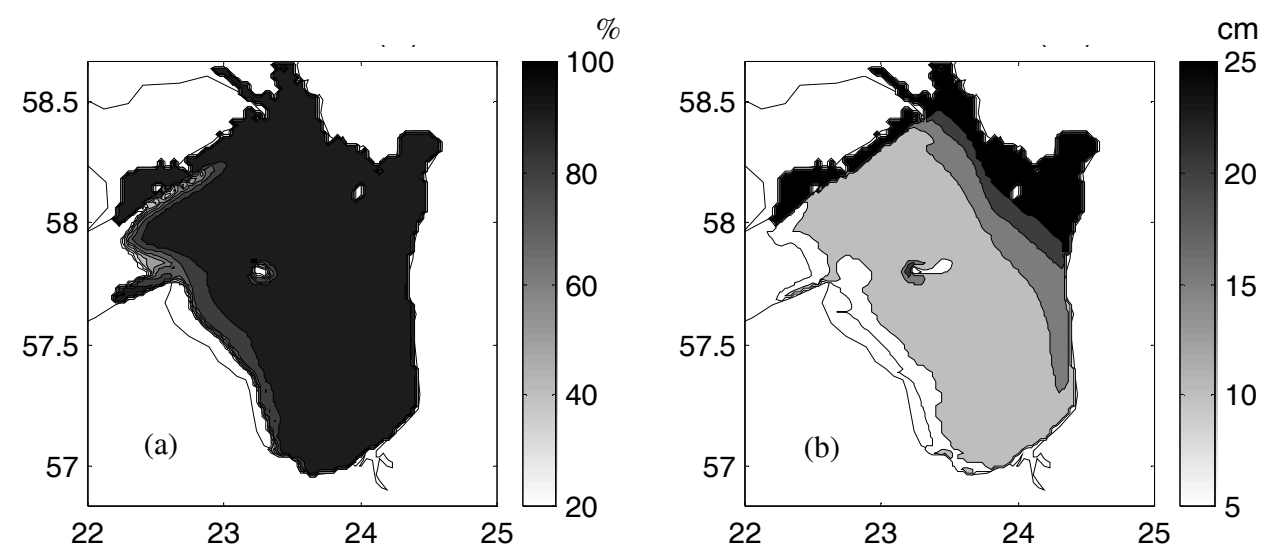

Fig. 12. Standard simulation for 19-22 January 1987: (a) ice concentration; (b) ice thickness.

was found when sea ice velocity fields from ERS-1 SAR are compared with model results in the Bay of Bothnia, northern Baltic Sea $\left[{ }^{15}\right]$.

The model outcome for 26 January shows some differences from the ice chart (Fig. 5). The ice chart shows a lead in the northern part of the basin but in the model two leads appear, both on the western side. Potentially, this could be due to the inaccuracy of the wind direction. Numerical experiments show that the desired result cannot be achieved even using different surface wind data or geostrophic wind data or changing the ice strength parameter. The reason for the disagreement remains open so far. 

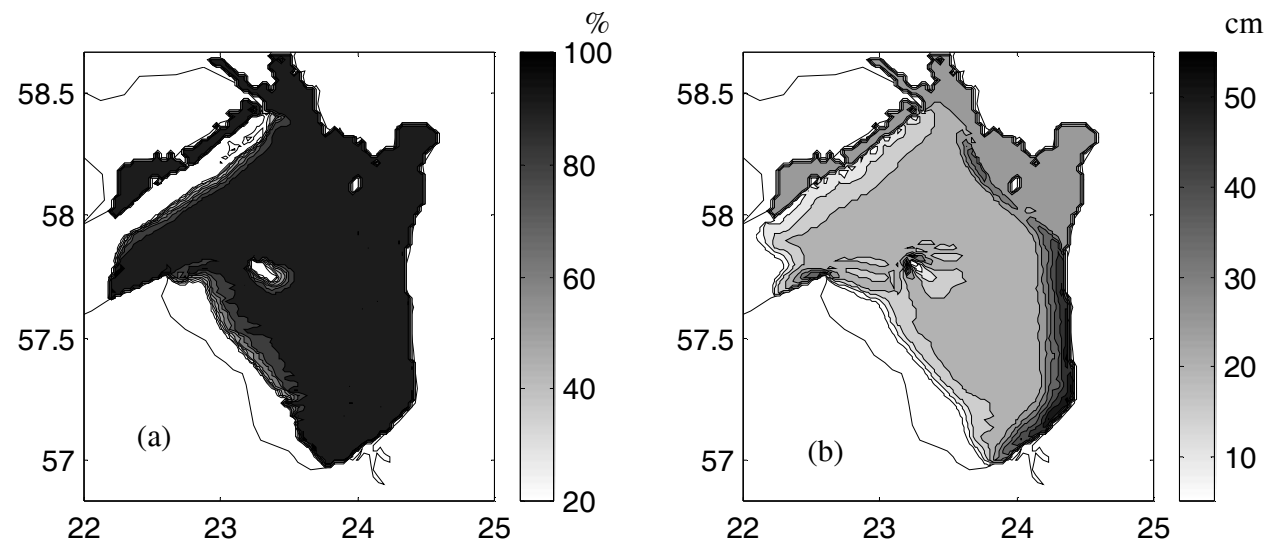

Fig. 13. Standard simulation for 22-26 January 1987: (a) ice concentration; (b) ice thickness.

In the simulated ice field for 29 January, the southern coast and the vicinity of the Ruhnu Island are the regions where the ice cover is most severely deformed (Fig. 14), which agrees quite well with ice charts. The model outcome for the total ice thickness along the southern coast is about $40 \mathrm{~cm}$, indicating heavy ridging with volume of ridged ice about half of the total ice volume. Additional
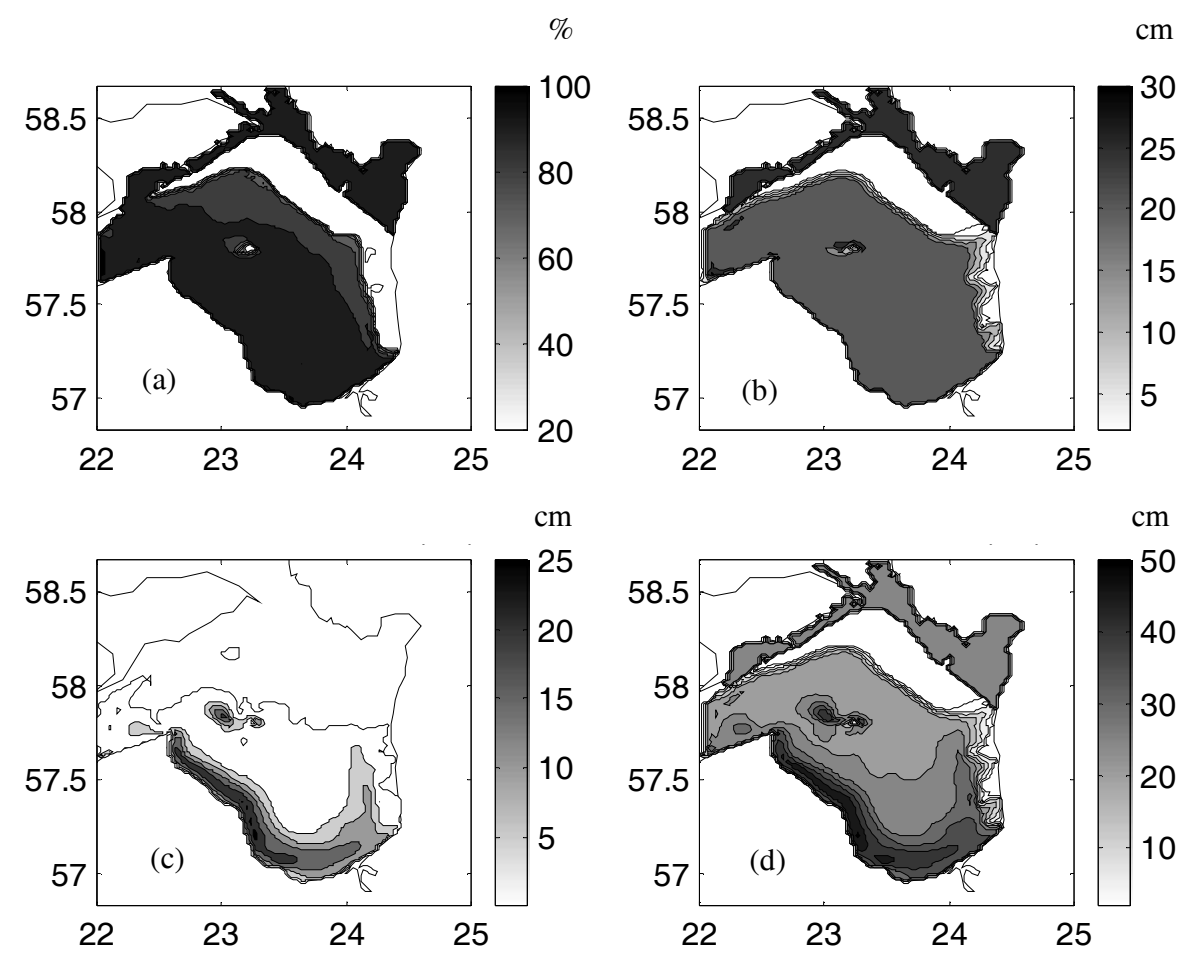

Fig. 14. Standard simulation for 26-29 January 1987: (a) ice concentration; (b) thickness of undeformed ice; (c) thickness of deformed ice; (d) total ice thickness. 

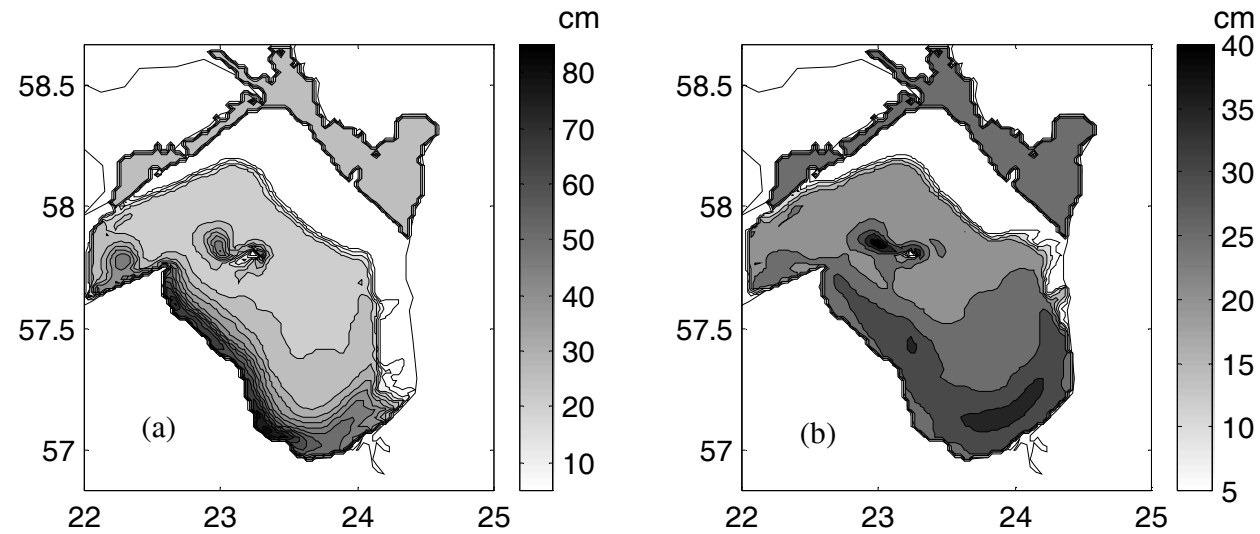

Fig. 15. Simulation of ice thickness for 26-29 January 1987 for different strength constants $P^{*}$ : (a) $P^{*}=1.0 \times 10^{4} \mathrm{~N} \mathrm{~m}^{-2}$; (b) $P^{*}=5.0 \times 10^{4} \mathrm{~N} \mathrm{~m}^{-2}$.

observation data is necessary to verify this result. Generally speaking, increasing the strength constant $P^{*}$ will slower the motion of ice cover and vice versa. Figure 15 shows the simulated result for high and low ice strength. The lead in $\mathrm{NE}$ reaches only half of the standard value along the eastern coast when $P^{*}=5.0 \times 10^{4} \mathrm{~N} \mathrm{~m}^{-2}$, and the deformed ice thickness along the southern coast reaches about $80 \mathrm{~cm}$ when $P^{*}=1.0 \times 10^{4} \mathrm{~N} \mathrm{~m}^{-2}$, which is considered unlikely high. This suggests that $P^{*}=3.0 \times 10^{4} \mathrm{~N} \mathrm{~m}^{-2}$ is a reasonable strength constant.

In most cases the model experiments support the ice strength parameter $P^{*}$ to be at the standard level used earlier in the Baltic Sea, i.e. $P^{*}=3.0 \times 10^{4} \mathrm{~N} \mathrm{~m}^{-2}$; this also lies within the range used in large scale sea ice models for the polar oceans $\left[{ }^{16,17}\right]$. The original value $\left[{ }^{3}\right]$ is low $\left(P^{*}=0.5 \times 10^{4} \mathrm{~N} \mathrm{~m}^{-2}\right)$ due to the 8 -day average wind data used. In $\left[{ }^{15}\right]$ the authors obtained $P^{*}=2.5 \times 10^{4} \mathrm{~N} \mathrm{~m}^{-2} \pm 50 \%$ in the Baltic Sea, based on the comparison of sea-ice velocity fields between ERS-1 SAR measurements and dynamic model simulations. Also other model parameters compared well with those in the Baltic Sea and polar ocean models.

\section{CONCLUSIONS}

A high-resolution model for drift of sea ice in the Gulf of Riga, Baltic Sea, has been presented. The basin size and ice thickness scale to $100 \mathrm{~km}$ and $20 \mathrm{~cm}$, respectively. The model is based on the conservation laws of ice mass and momentum with a three-level ice state (open water, undeformed ice, and deformed or ridged ice) and a viscous-plastic rheology. The grid size is $1 \mathrm{nmi}$ and the time step is $30 \mathrm{~min}$. Two cases of ice dynamics in the Gulf of Riga, with lengths of 21 and 11 days, have been examined, and the simulated results have been compared with available data - routine ice charts. Case 1 is typical for a normal winter with thin ice (less than $20 \mathrm{~cm}$ ), while Case 2 characterizes a severe winter with ice thickness up to $40 \mathrm{~cm}$. 
The ice strength parameter $P^{*}$ was optimized as $P^{*}=3.0 \times 10^{4} \mathrm{~N} \mathrm{~m}^{-2}$; this also lies within the range used in Baltic Sea ice models and in large-scale sea ice models for the polar oceans. Other model parameters were also well comparable with well-known models showing a strong similarity in the geophysics of sea ice in large seas (Arctic Ocean, scale $10^{3} \mathrm{~km}$ and grid size $10^{2} \mathrm{~km}$ ) and in small basins (Gulf of Riga, scale $10^{2} \mathrm{~km}$ and grid size $1 \mathrm{~km}$.

This model is capable to reproduce the main characteristics of dynamical ice drift and deformation processes in the Gulf of Riga. Thermodynamics was not included in this model and therefore active freezing and melting situations were not examined, which implies in particular that very early and very late winter and also intensive melting periods require still further work. On the other hand, available ice data for the Gulf of Riga are limited and their quality is relatively poor to make detailed model calibration. Therefore experimental studies on ice dynamics in the Gulf of Riga are necessary.

The present sea ice dynamics model shows good prognostic value for ice drift, rafting, and ridging in the Gulf of Riga. The resolution is high enough to explain basic processes in the drift ice mechanics, which is the most important navigational restriction in the Gulf of Riga, where ice is formed every year. During the last decade normal or mild winters dominated and the gulf was not totally frozen over; maximum thickness of undeformed ice was $10-15 \mathrm{~cm}$. Such ice cover is easily broken by wind. Fluctuation of the sea level, rafting, and ridging takes place in different parts of the Gulf of Riga depending on the wind conditions. In mild winters comparably fast changing ice conditions are observed in the Gulf of Riga and Pärnu bay, influencing remarkably the ship traffic, especially if ridging occurs. To plan a more efficient ice breaking service, there is a need to forecast ice conditions for some time in advance. However, nowadays such a forecast system is absent in Estonia and old empirical methods are still used by responsible Estonian authorities to describe the ice conditions, actually providing only an overview of the existing ice situation. The present new sea ice dynamics model could be successfully applied for operational ice service and ice forecast purposes in the Gulf of Riga.

\section{ACKNOWLEDGEMENTS}

The authors gratefully acknowledge the Finnish Centre for International Mobility CIMO, the Academy of Finland, and the Estonian Science Foundation (grant No. 4171) for financial support.

\section{REFERENCES}

1. Doronin, Yu. P. On a method of calculating the compactness and drift of ice floes. AIDJEX Bull., 1971, 3, 22-29.

2. Coon, M. D., Maykut, S. A., Pritchard, R. S., Rothrock, D. A., and Thorndike, A. S. Modeling the pack ice as an elastic-plastic material. AIDJEX Bull., 1974, 24, 1-105.

3. Hibler, W. D. A dynamic and thermodynamic sea ice model. J. Phys. Oceanogr., 1979, 9, 815-846. 
4. Zhang, Z. H. and Leppäranta, M. Modeling the influence of ice on sea level variations in the Baltic Sea. Geophysica, 1995, 31, 31-46.

5. Wu, H. D., Bai, S., Zhang, Z. H., and Li, G. Q. Numerical simulation for dynamical processes of sea ice. Acta Oceanol. Sinica, 1997, 16, 303-325.

6. Haapala, J., Alenius, P., Dubra, J., Klyachin, S. V., Kouts, T., Leppäranta, M., Omstedt, A., Pakstys, L., Schmelzer, N., Schrum, C., et al. IDA. Ice Data Bank for Baltic Sea Climate Studies. Report Series in Geophysics; Report No. 35. Department of Geophysics, University of Helsinki, 1996.

7. Leppäranta, M. The dynamics of sea ice. In Physics of Ice-Covered Seas, Vol. 1 (Leppäranta, M., ed.). Helsinki University Press, 1998, 305-342.

8. Zhang, Z. H. Comparisons between observed and simulated ice motion in the northern Baltic Sea. Geophysica, 2000, 36, 111-126.

9. Leppäranta, M. An ice drift model for the Baltic Sea. Tellus, 1981, 33, 583-596.

10. Jevrejeva, S. and Leppäranta, M. Ice conditions along the Estonian coast in a statistical view. Nordic Hydrol., 2002, 33, 241-267.

11. Suursaar, Ü., Astok, V., Kullas, T., Nõmm, A., and Otsmann, M. Currents in the Suur Strait and their role in the nutrient exchange between the Gulf of Riga and the Baltic Proper. Proc. Estonian Acad. Sci. Ecol., 1995, 5, 103-123.

12. Otsmann, M., Astok, V., and Suursaar, Ü. A model for water exchange between the Baltic Sea and the Gulf of Riga. Nordic Hydrol., 1997, 28, 351-364.

13. Parmerter, R. R. A model of simple rafting in sea ice. J. Geophys. Res., 1975, 80, 1948-1952.

14. Leppäranta, M. and Omstedt, A. Dynamic coupling of sea ice and water for an ice field with free boundaries. Tellus, 1990, 42A, 482-495.

15. Leppäranta, M., Sun, Y., and Haapala, J. Comparisons of sea-ice velocity fields from ERS-1 SAR and a dynamic model. J. Glaciol., 1998, 44, 248-262.

16. Hibler, W. D. and Walsh, J. On modelling seasonal and interannual fluctuations of Arctic sea ice. J. Phys. Oceanogr., 1982, 12, 1514-1523.

17. Hibler, W. D. and Ackley, S. F. Numerical simulation of the Weddell Sea pack ice. J. Geophys. Res., 1983, 88, 2873-2887.

\section{Liivi lahe merejää dünaamika mudel}

\section{Keguang Wang, Matti Leppäranta ja Tarmo Kõuts}

Mudel võimaldab simuleerida ja prognoosida Liivi lahe jääolusid erinevates hüdrometeoroloogilistes tingimustes. Vaadeldava mereala karakteristlikuks mõõtmeks on $100 \mathrm{~km}$, mis on üks väiksemaid basseine, kus seda tüüpi mudelit on rakendatud, ja iseloomulikuks jää paksuseks on $20 \mathrm{~cm}$. Jää mudel baseerub jää ja momendi jäävusel, kusjuures jääd käsitletakse viskoplastse reoloogiaga kolmetasandilise keskkonnana, jää tekke- ja sulamisprotsesse ei vaadelda. Jääolude tasanditeks on avavesi, deformeerumata jää ja deformeerunud (rüsistunud) jää, mis koos dünaamilise surutisega esitabki jää ümberjaotumisprotsessi mingil merealal. Mudeli vabad parameetrid määrati arvutustulemuste ja vaatluste põhjal koostatud jääkaartide võrdluse alusel. Need osutusid lähedasteks tervet Läänemerd esitava jäämudeli parameetritele. Mudeli üheks olulisemaks parameetriks oleva jääsurutise sisepinge koefitsiendi optimeeritud väärtuseks saadi $P^{*}=3,0 \times 10^{4} \mathrm{~N} \mathrm{~m}^{-2}$, mis osutus rakendatavaks tingimustes, kus termodünaamiline efekt (jää teke või sulamine) oli nõrk. Üle $10 \mathrm{~cm}$ paksuse jää puhul leiab aset rüsistumine ja õhema jää pealetriiv surutise toimel. 